\title{
Check the relation sexual satisfaction with marital stress, marital satisfaction and psychological symptoms of coronary artery bypass graft heart patients
}

\author{
Asieh Nekounam ${ }^{1}$, Soraya Etemadi ${ }^{2}$, Saeed Piranaghash Tehrani $^{3}$ \\ 1-Master of Clinical Psychology, Farabi Campus of Tehran University, Qom, Iran (Corresponding Author). ORCID: \\ 0000-0001-9071-4514Ｅ-mail: asieh.neko.nam@ut.ac.ir \\ 2- Associate Professor of Psychology, Farabi University of Tehran, Qom, Iran. ORCID: 0000-0003-3972-1123 \\ 3- Associate Professor of Psychology, Faculty of Psychology and Educational Sciences, University of Tehran, \\ Tehran, Iran. ORCID: 0000-0003-2273-6038
}

Received: $26 / 11 / 2018$

Accepted: 16/02/2019

\begin{abstract}
Introduction: Heart disease is one of the most commonly known diseases around the world.

Aim: This study aims to investigate the status of sexual satisfaction with marital stress, matital satisfaction and psychological symptoms of coronary artery bypass patients and their relationship.

Method: This study is descriptive-correlational. The sample of this study was a group of 300 people who were selected in a targeted way among cabg heart patients who were referred to Tehran Heart Hospital to participate in a rehabilitation program. Hudson Sexual Satisfaction, Anrich 47, Tehran Stockholm Marital Stress and Dass 21 Questionnaires were used for data collection. Pearson Descriptive and Correlative Statistics and spss-24 Multivariable Regression were used for analysis.
\end{abstract}

Results: In the findings of this study, there was a reverse and significant correlation between sexual satisfaction and depression, stress, anxiety and marital stress, but there was no significant correlation between sexual satisfaction and marital satisfaction. The result of Multiple Regression Analysis showed that marital satisfaction, marital stress, anxiety, depression and stress structures can explain $0.01 \%$ of changes in sexual satisfaction.

Conclusion: It can be said that by controlling each of these components, other psychological components will be affected.

Keywords: Sexual satisfaction, Marital satisfaction, Marital stress, Psychological symptoms, Heart disease

How to cite this article : Nekounam A, Etemadi S, Piranaghash Tehrani S. Check the relation Sexual satisfaction with marital stress, marital satisfaction and psychological symptoms of coronary artery bypass graft heart patients. Shenakht Journal of Psychology and Psychiatry. 2019; 6 (2): 16-26 .URL :http://shenakht.muk.ac.ir/article-1-432-fa.pdf

Copyright (C) 2018 the Author (s). Published by Kurdistan University of Medical Sciences. This is an open access article distributed under the terms of the Creative Commons Attribution-Non Commercial License 4.0 (CCBY-NC), where it is permissible to download, share, remix, transform, and buildup the work provided it is properly cited. The work cannot be used commercially without permission from the journal. 


\title{
بررسى رابطه رضايت جنسى با استرس زناشويى، رضايت زناشويى و علائم روانشناختى بيماران قلبى باى هي عروق كرونر
}

\author{
آسيه نكونام'، ثريا اعتمادى'، سيد سعيد يورنقاش تهرانى

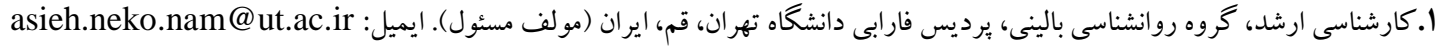

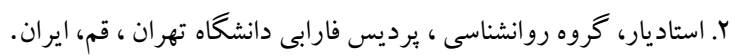

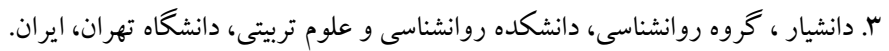
هدف: يزوهش حاضر با هدف بررسى وضعيت رضايت جنسى با استرس زناشويى، رضايت زناشويى و علائم روانشناختى بيماران قلى باى يس عروق كرونر و رابطه بين آنها اجرا شد.

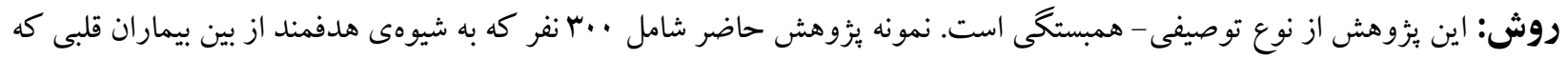

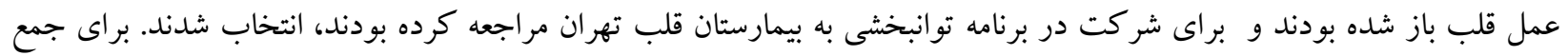

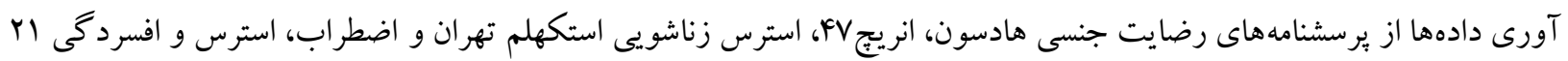

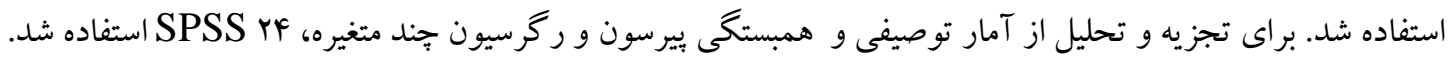
يافتهها: يافتهاى بدست آمده از يُوهش حاضر بين رضايت جنسى با افسردگى، استرس، اضطراب و استرس زناشويى همبستكى

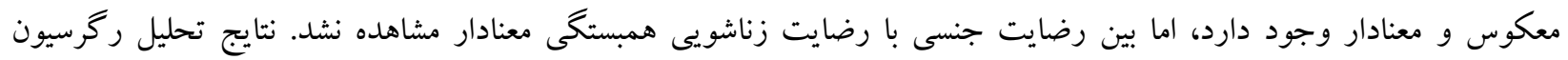

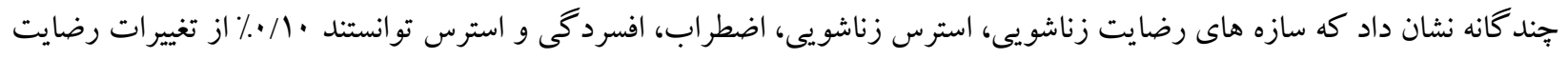
جنسى تبين كنند. نتيجه كيرى: مى توان كفت با كنترل هر يكك از اين مولفها ساير مولفهاى روانشناختى تحت تاثير قرار خواهند گرفت. كليدوازهها: رضايت جنسى، رضايت زناشويى، استرس زناشويى، علائم روانشناختى، بيمارى قلبى 
صرفا تجربه يا عدم تجربه ار گاسم نيست. رابطه جنسى و

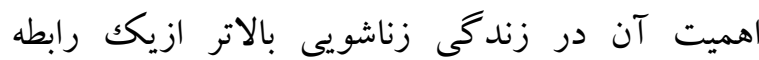
فيزيكى و جسمى است و نوعى انرزى است كه افراد را بر مىانگيزد تا عشق و عاطفه و صميميت را در بين خودبه وجود بياورند. اين روابط در زندكى مشترك به همان ميز انى كه جنسى و جسمى است، حسى مىباشد. يكى از متغيرهاى بسيار مهم و مؤثر در رضايت جنسى، كيفيت و جֶ) تحقيقات متعدد، ارتباط معنادارى بين رضايت جنسى و رضايت از تعاملات و ارتباطات زناشويى را به اثبات رساندهاند (حجت يناهى و همكاران، سابـr). در بيمارى قلبى عروقى مشكلات جنسى شيوع بالايى دارد كه منجر به كاهش كيفيت زندگى بيماران مىشود

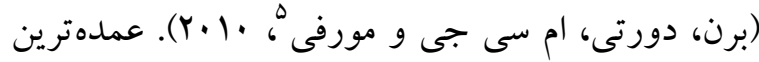

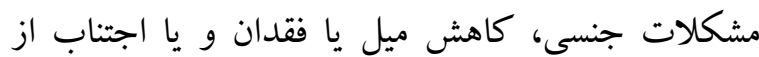
فعاليت جنسى است كه در نهايت منجر به نارضايتى

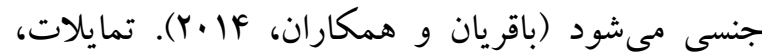
كششها و كيفيت زندكى جنسى انسان به اندازهى اصل زيستن، بيربار و بيبيجيده است. فعاليت جنسى و جنسيت، ... بخش مهمى از زندكى زناشويى است (ديويس، شاور،

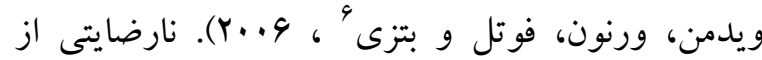
رابطه جنسى، مىتواند به مشكلات عميق در روابط زوجين و ايجاد تنفر از همسر، دلخورى، حسادت، رقابت، حس انتقام و احساس عدم اعتماد به نفس منجر شود

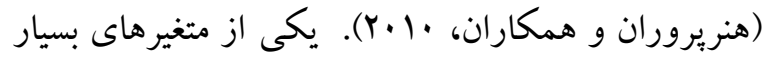

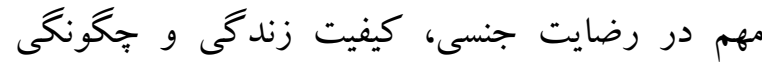
ارتباط زوجين با يكديخر است. تحقيقات متعدد ارتباط

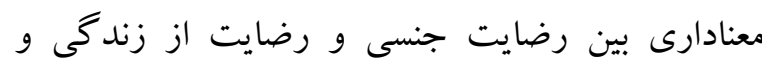

${ }_{6}^{5}$ Byrne, Doherty, McGee, Murphy

${ }^{6}$ Davis, Shaver, Widaman, Vernon, Follette, Beitz
مقلهمه بيمارى قلبى عروقى كرونر 'يكك مشكل عمده بهداشت عمومى در سراسر جهان است كه منجر به مرگك مردان و

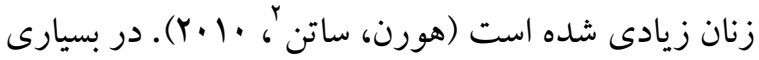
موارد، جراحى باى بِ عروق كرونر قلب تنها راه درمان و افزايش طول عمر بيماران مىباشد (سياووشى و و لونى

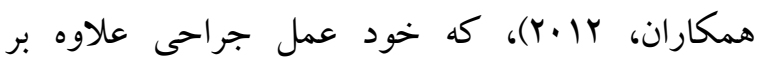
بهبودى، موجب آسيبهايى مىشود، مانند انواع

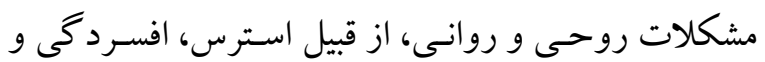
اضطراب كه معمولا بعد از عمل جراحى قلب براى بيماران اتفاق مىافتد، مىباشد (تهرانى و همكاران، $(r \cdot 1 r$ على الرغم موثر بودن اين درمان كماكان بيماران با مشكلات ديكرى دست و وينجه نرم مى كنند كه همين مشكلات خطر عود مجدد رادر يى دارد؛ اين مشكلات مىتوانند عواملى هماند فشار روانى، تعارضات بين فردى و رفتارهاى خصومت آميز كه به بسترى شدن مجدد بيمار

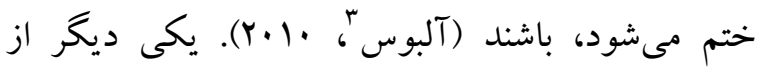
عو املى كه تحت تاثير بيمارى قلبى قرار مى گيرد فعاليت جنسى است. طبق مطالعات انجام شده يكى از نيازهاى

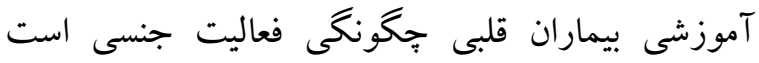

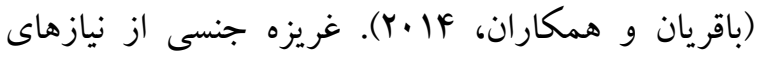
ذاتى انسان است. به طورى كه مزلو باين نياز را در رده نيازهاى جسمانى يا نيازهاى حياتى اوليه قرار داده است. رابطه جنسى يك الزام زيستى براى هر موجود زنده و بالغ است. به كفته سازمان جهانى بهداشت، رابطه جنسى بين زوجين، مترادف با مقاربت جنسى نيست و هدف آن

${ }^{1} \mathrm{CHD}$

${ }^{2}$ Heron, Sutton

${ }^{3}$ Albus

${ }^{4}$ Maslow 
سلامت روان بيماران مبتلا به سرطان به اين نتيجه دست يافتند كه بين سلامت روان و عملكرد جنسى رابطه وجود دارد (شايان و همكاران، 19)

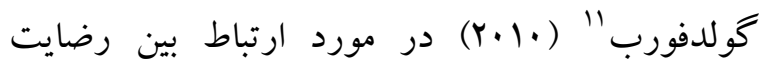
جنسى، عملكرد زناشويى، افسردگى و اضطراب؛ به اين نتيجه دست يافنند كه بين هر كدام رضايت جنسى؛ عملكرد زناشويى و اختلال اضطراب، افسردگى رابطه وجود دارد و با كنترل هر كدام مىتوان ديخرى را نيز بهبود بخشيد. در يثوهشى دربارهى زنان مبتلا به بيمارى كرونرى قلب و زنان سالم نشان دادند كه استرس زناشويى هم در زنان مبتلا به بيمارى قلبى و هم در زنان سالم علائم افسردگى رابطه دارند (شمسى بيور و و

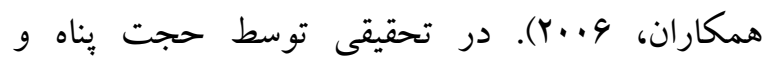
همكاران (r/r) بين رضايت جنسى و رضايت زناشويى و رضايت از زندگى رابطه معنادار وجود دارد. اين بيمارى، به دليل ماهيت ناتوان كننده، داراى بيامدهاى فيزيكى، روانى و اجتماعى متعددى است، كه ساز گارى بئ ضعيف و نتايج اين ييامدها مىتوانند بر رضايت جنسى مبتلايان تأثير منفى بكذارد. عدم رضايت جنسى موجب كاهش در سلامتى، كاهش طول عمر، عدم رضايت از زندگى و همجنين، اختلال در رشد و تعالى زوجين و و كستگگى رابطه زناشويى و كاهش رضايت زناشويى

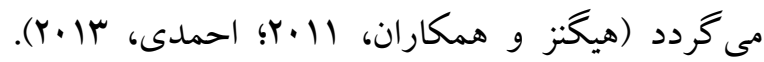
بنابر اين با توجه به حساس بودن نقش قلب در سلامت و

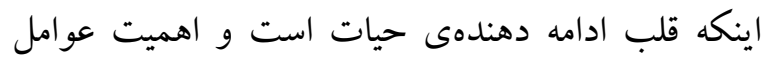

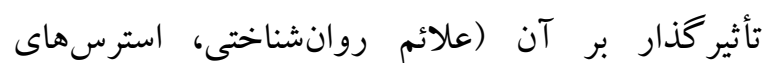
زناشويى و رضايت زناشويى و رضايت جنسى) و همجنين

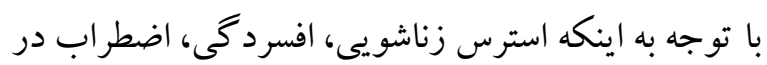

\footnotetext{
${ }^{11}$ Trudel, Goldfarb
}

تعاملات و و ارتباطات زناشويى را به اثبات

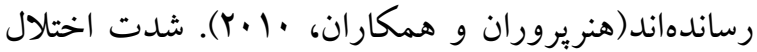
عملكرد جنسى با بيمارى قلبى رابطه دارد در واقع بين بيمارىهاى قلبى مشكلات تعوظ شدت ييدا مى كند. شدت انسداد عروق كرونر، خطرات در زندگى جنسى به

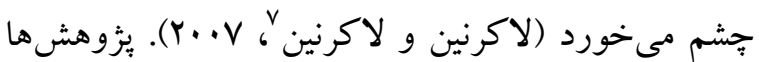
نشان دادهاند كه درميان متغيرهاى روانى- اجتماعى، استرس حاد و مزمن از عمدهترين عوامل خطر براى بروز و سير بيمارى كرونرى قلب هستند (باربيبورات، فليكس، دآزود، كامبيرا، ولجان، مسكايتا، دومن و مسكويتا؛

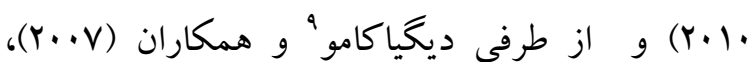
استرس را از شايعترين ييامدهاى نامطلوب بيمارىهاى عروق كرونر مىدانند و معتقدند كه اين بيامدها در نهايت سير اين دسته از بيمارىهاى قلبى را بدتر و وخيمتر مى سازند. استرس زناشويى به عنوان نوعى استرس روانى اجتماعى، فرايند جند عاملى است كه شامل تعارضات بين فردى در محيط خانو ادگى، راهبردهاى مقابلهاى ناكار آمد و همراه با مجموعهاى از ياسخهاى عصبى- غددى، عملكرد سيستم خود كار و قلبى- عروقى و نيز بِاسخهاى فيزيولوزيكك به تنشهاى روانى -اجتماعى است (رحيميان

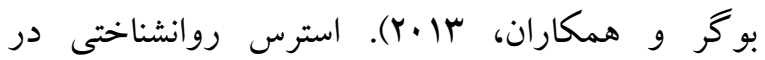
خانواده، عامل تسريع كننده ايسكمى ميو كارد و آنزين در بيماران مبتلا به بيمارى كرونرى تلقى شده است (وانگگ، لئونوبر، كير كيد، اسوان، اسجن كاسفون، ترول و و

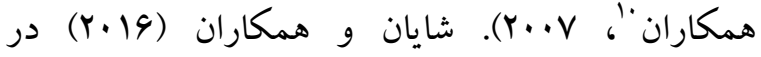
تحقيقى تحت عنوان بررسى رابطه عملكرد جنسى با

\footnotetext{
${ }^{7}$ Lukkarinen \& Lukkarinen

${ }^{8}$ Barbirato, Félix, de Azevedo, Corrêa, de Nóbrega, Coimbra, Volschan, Mesquita, Dohmann, and Mesquita

${ }^{9}$ Digiacomo

${ }^{10}$ Wang, Leineweber, Kirkeeide, Svane, Schenck-Gustafsson, Theorell, and Orth-Gomér
} 
رضايت زناشويى انريج- FV و زيرسشنامه اضطراب، استرس و افسردگى آ استفاده شد.

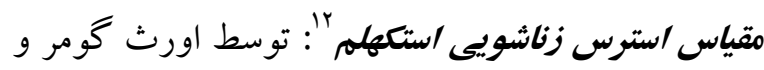

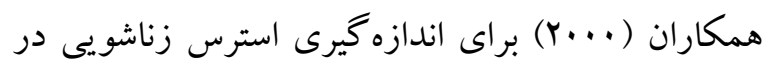
زنان مبتلا به بيمارى قلبى ساخته شد. مقياس اصلى داراى IV سوال است كه بهصورت صفر ويكك نمره گذارى مىشود. حداقل نمرة اين مقياس صفر و حداكثر نمره آن

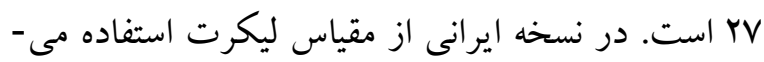
شود، در نهايت فرم 19 سوالى مقياس تهيه شد به صورت

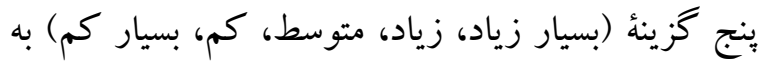

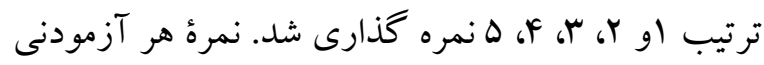

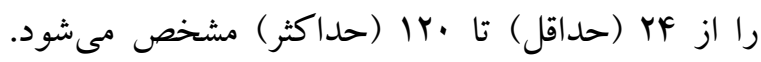
ضريب همبستخى مقياس زناشويى استكهلم - تهران VA/. محاسبه شد كه در سطح l p= معنى دار بود (شمسى

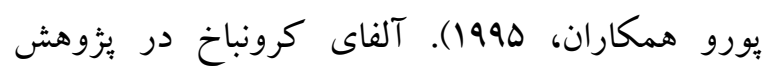

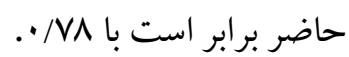

يرسشنامه رضايت جنسى هادسون: ها گ گ يه دارد. در سال 1911 توسط هادسون- هريسون و كروسكاب براى ارزيابى سطوح رضايت زوجين ساخته شد. پاسخ آزمودنى به هر ماده آزمون در سطح يك مقياس ل درجهاى بين · تا 4 مشخص مى شود و در مجموع نمره آزمودنىها در كل تست بين · تا •ها در نوسان است.

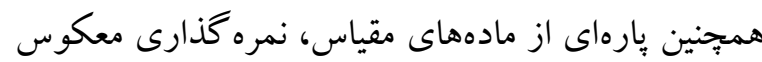

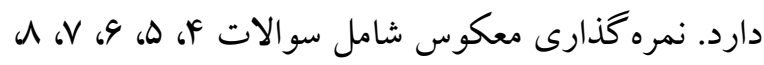

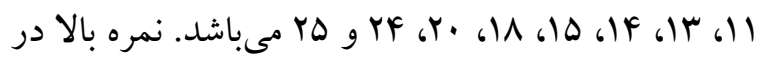
اين مقياس منعكس كننده رضايت جنسى است. ثبات درونى اين مقياس توسط طراحان محاسبه و آلفاى كرونباخ آن آن/ · بدست آمد (روشنى و همكاران،
بين بيماران قلبى به شدت بالاست در حاليكه رضايت جنسى و رضايت زناشويى آنها در درجه يايين قرار دارد. به همين منظور يزوهش حاضر با هدف بررسى رابطه رضايت جنسى با استرس زناشويى، رضايت زناشويى و علائم روانشناختى بيماران قلبى باى پِّ عروق كرونر

$$
\text { صورت گرفت. }
$$

روش

يثوهش حاضر از نوع توصيفى- همبستخى است كه در قالب ييش بينى اجرا مىشود. نمونه يزوهش حاضر به صورت هدفمند انتخاب شدند. نمونه از بين بيماران قلبى كه جراحى عمل قلب باز شده بودند و براى شركت در برنامه توانبخشى به بيمارستان قلب تهران مراجعه كرده بودند انتخاب شدند. به دليل اينكه در بيمارستان قلب، بازتوانى به صورت دورهاى اجرا مىشد و معمولا در هر

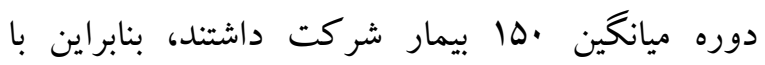
هماهنكى بيمارستان، همدى افراد شركت كننده در دو دوره به عنوان نمونه در نظرگرفته شد كه مجموعا ... نفر به عنوان نمونه انتخاب شدند. معيار ورود به تحقيق شامل: متاهل بودن، داشتن رضايت جهت شركت در يزوهش، داشتن بيمارى قلبى و درمان از نوع عمل جراحى قلب باز و نداشتن مشكلات شناختى معيار خروج شامل: تجرد، عدم رضايت و تمايل براى ادامه روند يُزوهش، درمان هاى ديخر قلبى.

ابزار براى جمع آورى دادهها از يرسشنامههاى رضايت جنسى

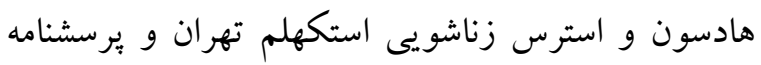

\footnotetext{
${ }^{12}$ SMSS
} 
اضطر اب و 19-19 براى استرس نشانه داشتن مشكلات در سطح متوسط مىباشد. كسب نمره

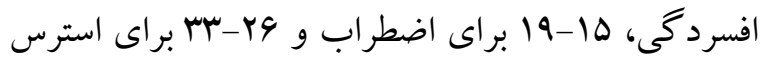
نشانه داشتن هر يكك از اين مشكلات در سطح شديد

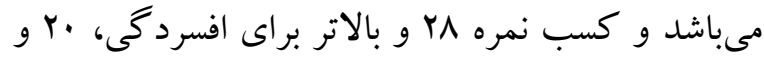
بالاتر براى اضطراب و F و و بالاتر براى استرس نشانه داشتن مشكلات در سطح خيلى شديد مىباشد (صاحبى و

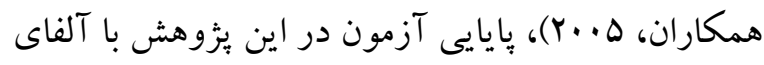
كرونباخ محاسبه شده كه 19/ • بدست آمد. ״س از جمع آورى دادهها با استفاده از آمار

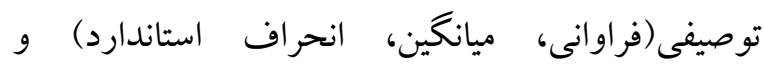

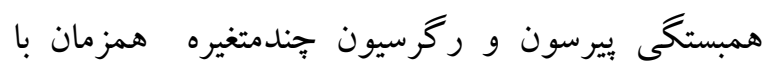
استفاده از نرم افزار SPSS YF دادهها تجزيه و تحليل شد.

\section{يافته ها}

در يزوهش حاضر تعداد آقايان كنند كان خانم بودند. ميزان تحصيلات شر كت كنند كان

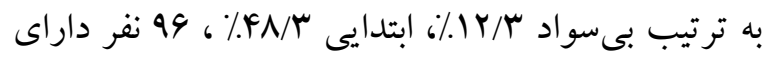
مدرك دييلم و س/YYY\% در مقطع ليسانس قرار داشتند و در

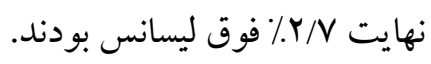

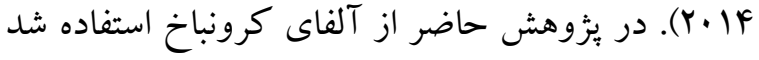
كه آلفا برابر با ع/A/ • به دست آمد. يرسشناملى رضايتمنلدى زناشويع انزيج: توسط اولسون،

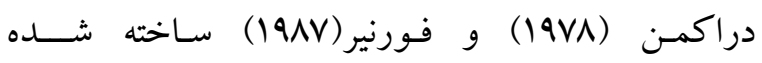
اســت. نسخه اصالى داراى هال ســــوال و rا مقيــاس كه روى مقياس ه درجهاى ليكرت از ه-ا نمره گذارى مىشـود كه در اين يثوهش از فرم FV سوالى اين

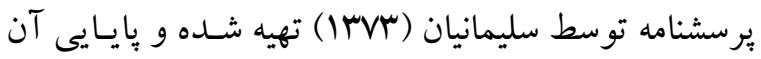

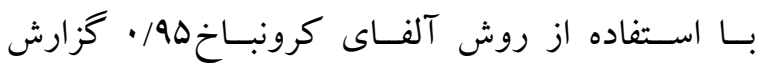
شده است (اميرى و همكاران، · · (Y). برسشنامه اضطراب، استرس و افسردكى: اين يرسشنامه

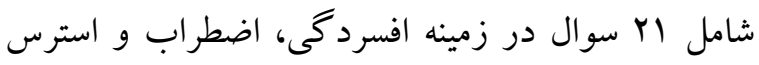
مىباشد. نحوه نمره گذارى (از گزينه درمورد من صدق نمى كند= صفر تا كزينه كاملا صدق مى كند= يكك)

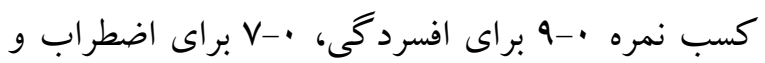

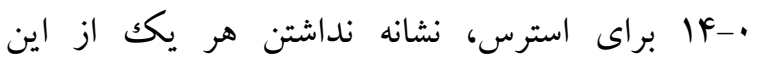

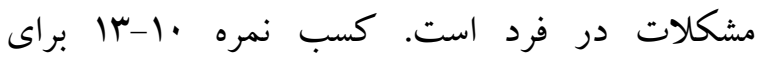

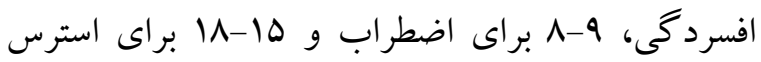
نشانه داشتن هر يكك از مشكلات در سطح خفيف

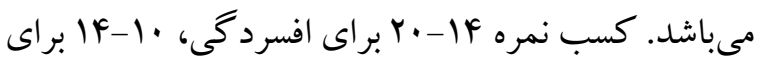

جدول 1 ميانكين و انحراف استاندارد ( سن، رضايت زناشويى، علائم روانشناختى، استرس زناشويى)


شامل مىشد. ميزان اضطراب در حد متوسط داراى يكك

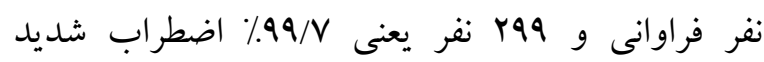

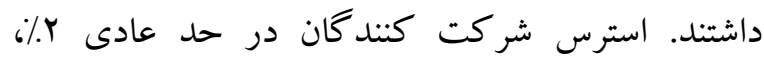

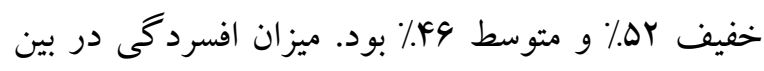

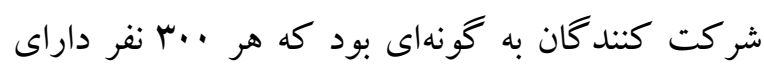

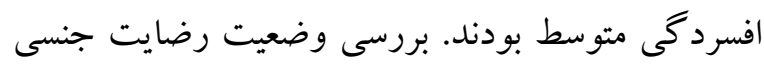

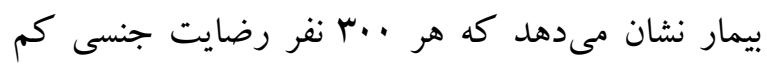

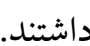

براساس جدول ا ميانكين سنى شركت كند كان بو سال

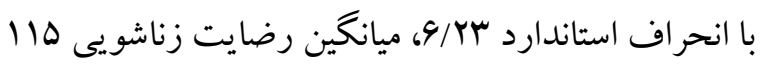

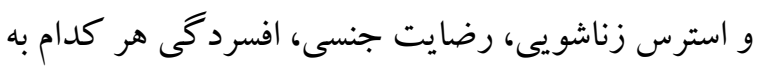
ترتيب 19/9F ه

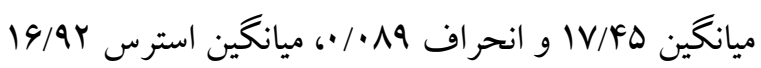
مىباشد. در بين شر كت كند كان 91//\% نارضايتى زناشويى شديد

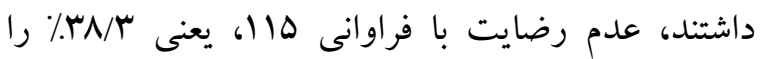

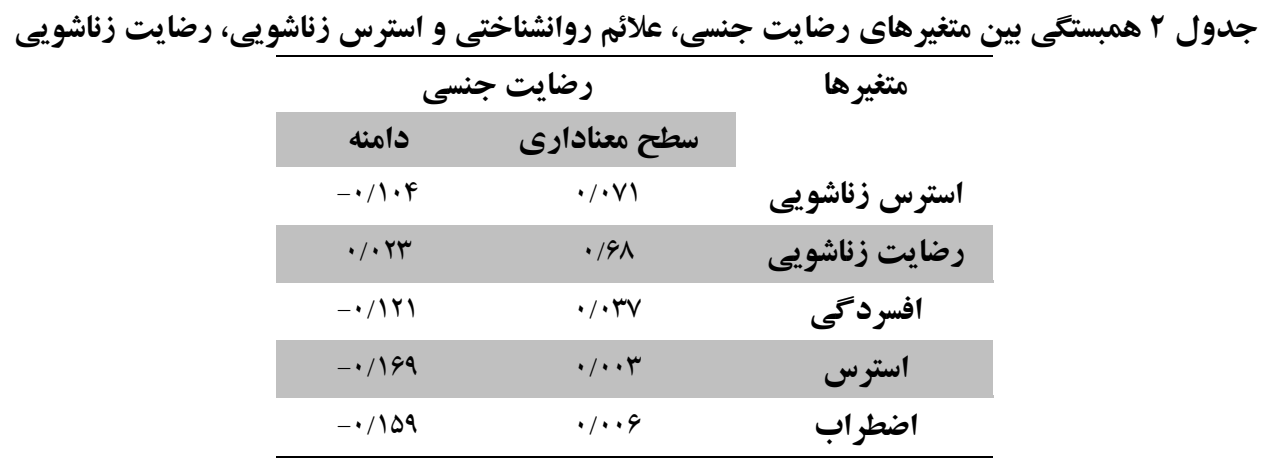

بين ميزان افسردگى و رضايت جنسى همبستخى معكوس براساس جدول Y بين استرس زناشويى و رضايت جنسى

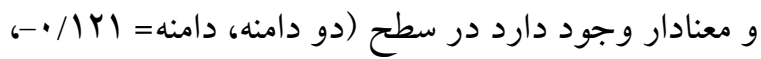

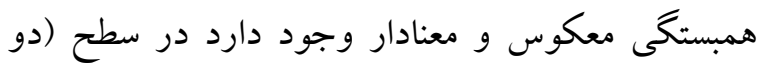

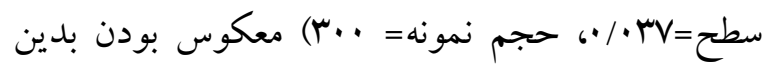

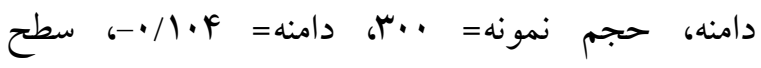
معناست كه با افزايش افسردگى رضايت جنسى بيماران

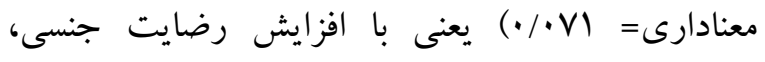

$$
\text { قلبى كاهش مىيابد. }
$$$$
\text { استرس زناشويى كاهش مى يابد. }
$$

در مورد همبستخى بين اضطراب و رضايت جنسى در اين

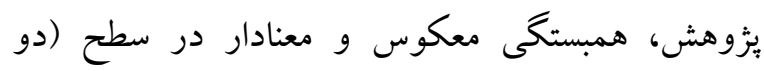

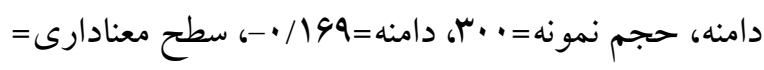

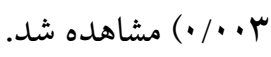
همجنين بين رضايت زناشويى و رضايت جنسى در اين اين

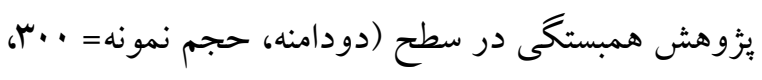

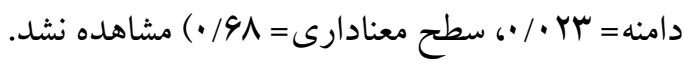

جدول ب تحليل رترسيون همزمان متغيرهاى ثروهش

\begin{tabular}{|c|c|c|c|c|c|c|c|}
\hline ضعريم يافته & ضريب & معنادارى سطح & ضرينان(فيشر) & مجذورات & درادى & مجذورات & ركرسيون \\
\hline \multirow[t]{2}{*}{.$/ 1$} &.$/ . r$ & .1 .4 & $r / . q$ & $Q / \wedge \Delta$ & $\Delta$ & $F q / Y \Delta$ & ركرسيون \\
\hline & & & & r/99 & raf & $|r N| / 9 r$ & باقيمانده \\
\hline
\end{tabular}


از جمله مشكلات روانشناختى كه بيماران قلبى با آن روبرو هستند افسردكى است كه مانع مداواى بيمارى مىشود زيرا افسردگى باعث مىشود بيمار انكيزهاى براى مونى

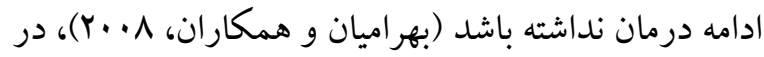
كنار افسردگى، اضطراب ناشى از عمل جراحى قلب را نمىتوان ناديده كرفت. عمل جراحى قلب باز، يكى از اضطراب انخيزترين وقايعى است كه ممكن است در

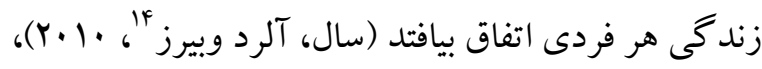
نتايج مطالعات نيز نشان داده كه ميزان بروز اضطراب قبل و بعد از عمل جراحى به ترتيب از بF به MF/V مىرسد (كرانيك،، ويرز، لو گر،، هرزو اين اضطراب و افسردگى با كاركرد جسمانى، ناتوانى و كيفيت زندكى بيماران قلبى مزمن رابطه دارد (جين، لى و و

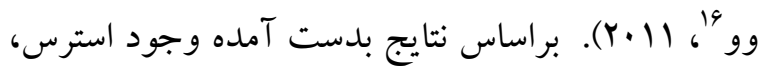

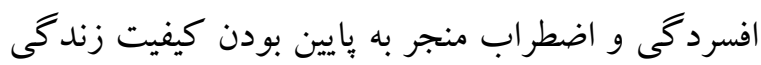
بيماران قلبى شده است، از آنجايى كه فعاليت جنسى نقش مهمى در وضعيت كيفيت زندگى دارد و تيم درمانى تنها بر بايه حفظ و ادامه زندگى بيماران تمركز مى كنند و به عملكرد جنسى بيمار ان كمتر توجه مى كنند،

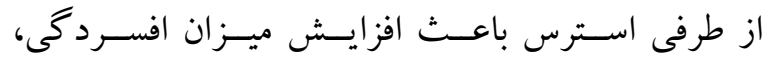

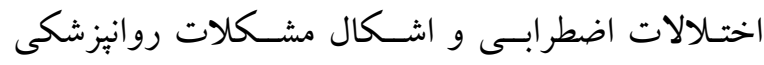
مىشوند (لنجر، شلتن، ريج، بارتا، جانسن مالارد و و إنى

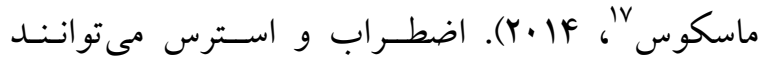
تأثيــر فيزيولوزيــك مسـتقيم بــر عملكــرد سيسـتم

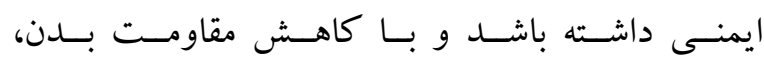
فـرد را مسـتعد تشـديد بيمـارى جسـمانى و روانسى كنــــد و از ايـن طريـق مىتوانـند عملكـرد روز مـره و

${ }^{14}$ Allred, Byers, Sole

${ }^{15}$ Krannich, Weyers, Lueger, Herzog, Bohrer, Elert

${ }^{16}$ Chien, Lee, Wu

${ }^{17}$ Lengacher, Shelton, Reich, Barta, Johnson-Mallard, Moscose
باتوجه به نتايج تحليل واريانس و شاخصهاى آمارى ركرسيون متغيرهاى بيش بين بر ميزان رضايت جنسى، مقدارF بدست آمده براى بينج متغير استرس زناشويى، افسردگى، اضطراب، استرس و رضايت زناشويى معنادار

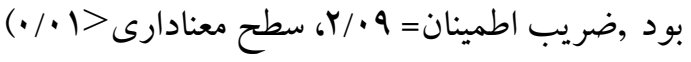
از طرفى بين متغيرهاى رضايت زناشويى، استرس

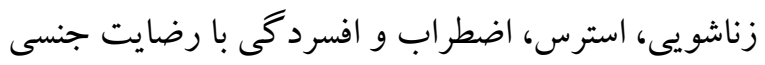
رابطه معنى دار ديده مى شود (ضريب تعيين= س./•) و اين متغيرها قادرند در مجموع (ضريب تعيين تعميم يافته= | • • از رضايت جنسى را تبين كنند.

اين يزٔوهش با هدف بررسى رابطه بين رضايت جنسى با استرس زناشويى، رضايت زناشويى و علائم روانشناختى بيماران قلبى صورت گرفت. براساس يافتهاى بدست آمده از اين ئزوهش بين رضايت جنسى و استرس زناشويى و علايم روانشناختى رابطه معنادار و معكوس وجود دارد يعنى با افزايش رضايت جنسى هر كدام از مولفه هاى ديخر كاهش مى يابند، اما بين رضايت جنسى و رضايت زناشويى در اين إزوهش همبستخى معنادارى مشاهده نشد. نتيجه اين يُزوهش با تحقيق حجت يناه درمورد رابطه بين رضايت جنسى با رضايت زناشويى ناهماهنگ است. همجِنين با بُزوهش شايان و همكاران (هوسו) در مورد رابطه بين عملكرد جنسى با سلامت روان همسو است و با تحقيق ترودل و همكاران در مورد رابطه بين رضايت جنسى با زناشويى ناهماهنگك و رابطه با

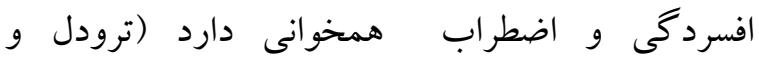

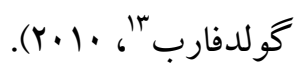

\footnotetext{
${ }^{13}$ Trudel, Goldfarb
} 


\section{نتيجه گيرى}

بيشتر بيماران قلبى از وجود افسردگى، اضطراب، استرس و استرسهاى زناشويى و عدم رضايت جنسى و زناشويى رنج مىبرند، از آنجايى كه در اين بثزوهش بين تكك تكك مولفههاى روانشناختى با رضايت جنسى همبستخى وجود داشت بهتر است، در زمينه مسائل جنسى و روابط زناشويى و علائم روانشناختى به بيماران قلبى شـناخت و آكاهـى داده شود. در ايـن بيمـاران الزم اسـت وضعيـت عملكرد جنسى و نـوع تغييـرات ايجـاد شـده مــورد

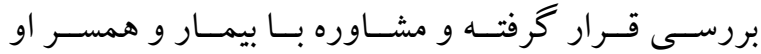
در زمينه نحـوه مشـكلات و ابـراز احساسـات انجـام شـود و همجِنين آموزشهاى در زمينهى كاهش علائم روانشناختى داده شود تـا از فشـارروانى آنـان كاسته شـود و رونــد بهبـودى بيمـارى سـريعتر اتفاق بيافتد.

\section{سياسگز ارى}

از كليهى برسنل بيمارستان قلب تهران و همجِنين بيماران قلبى كه ما را در اجراى اين يثزوهش يارى كردند تشكر و

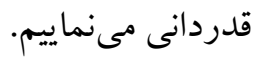

\section{References}

Albus C. Psychological and social factors in coronary heart disease. Annals of medicine; 2010.42(7), 487-494.

Allred K. D, Byers J. F, \& Sole M. L. The effect of music on postoperative pain and anxiety. Pain Management Nursing; 2010.11(1), 15-25.

Amiri Majd M, Zari Moghadam F. [Relationship Between Happiness and Marital Satisfaction among Employed Cultural Women and Housewives in Arak].2010. 2 (4), 9-21. (In persian).

Bagherian A, Architects R, Hajizadeh A, Clean eye b. [The effect of sexual education on satisfaction
اجتماعى ايسن افراد را تحـت تأثيــ قـرار دهـــ. عمده

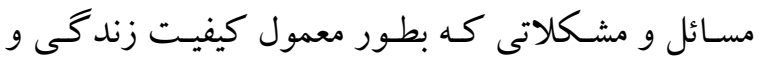

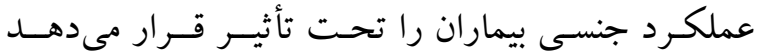
شـامل آثـار روانسى و عاطفـى ناشـى از ابتـلـا بــه بيمـارى و اقدامــات تشـخيصى و درمانسى، اسـترس و و ... اســت كـه ايـن اسـترسهاى روانسى و رفتـار مراقبـت

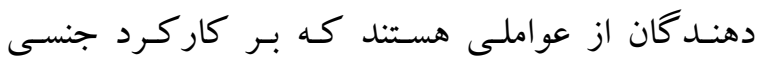
بيمـاران تأثيـر مى خـذارد. رضايت جنسى، با افزايش صميميت بين زوجها، افزايش رضايت آنها از يكديخر و در نتيجه افزايش سلامت روان آنها مىشود (يو، بارتل -

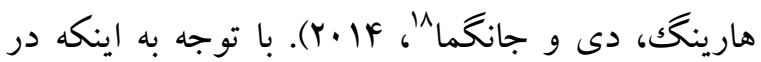
اين ئزوهش بين رضايت زناشويى و رضايت جنسى رابطهاى مشاهده نشد اما در ساير تحقيقات همبستخى بين اين دو مولفه به اثبات رسيده است. رضايت زناشويى و رضايت جنسى بر كيفيت وميزان سلامت روان و ميزان

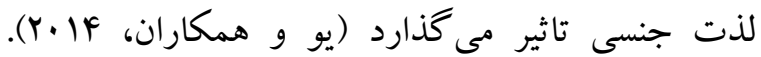
رضايت زناشويى از روابط زوجين تاثير مى يذيرد و تاثير بذيرى به نوبه خود منجر به مشكلاتى در روابط وآسيب

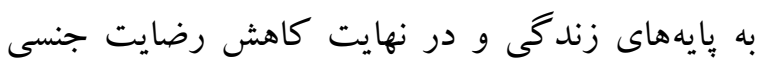

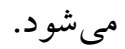
اضطراب عملكرد و ترس از مرگك نقش برجستهاى و بروز ناتوانى جنسى در بيماران قلبى دارد. ضمنا اضطراب

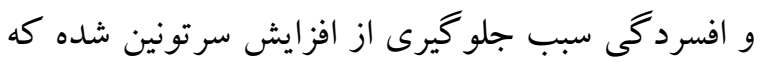
در نتيجه آن كاهش عملكرد جنسى بيماران مىشود و همين كاهش عملكرد جنسى منجر به كاهش رضايت جنسى و در نهايت رضايت زناشويى شود و ادامه اين جرخه منجر به حمله مجدد قلبى مىشود.

\footnotetext{
${ }^{18}$ Yoo, Bartle-Haring, Day, Gangamma
} 
of patients and spouses after myocardial infarction]. Journal of Hakim Jarjani2014. 2 (1), 46-40. (Persian)

Barbirato G.B, Félix R, de Azevedo J.C, Corrêa P.L, de Nóbrega A.C, Coimbra A, Volschan A, Mesquita E.T, Dohmann H.F, and Mesquita C.T. Prevalence of induced ischemia by mental distress. Arquivos Brasileiros de Cardiologia; 2010. 94(3), 301-7.

Byme M, Doherty S, MoGee H. M, \& Murphy A. W. General practitioner views about discussing sexual issues with patients with coronary heart disease: a national survey in Ireland. BMC family practice; 2010. 11(1), 40.

Chien C.-L, Lee C.-M, Wu Y.-W, \& Wu Y.-T. Home-based exercise improves the quality of life and physical function but not the psychological status of people with chronic heart failure: a randomised trial. Journal of physiotherapy; 2011.57(3), 157-163.

Davis D, Shaver P. R, Widaman K. F, Vernon M. L, Follette W. C, \& Beitz K. 'I can't get no satisfaction": Insecure attachment, inhibited sexual communication, and sexual dissatisfaction. Personal Relationships; 2006. 13(4), 465-483. 4.

Heron M, Sutton P. D, Xu J, Ventura S. J, Strobino

D. M, \& Guyer B. Annual summary of vital statistics: 2007. Pediatrics; 2010. 125(1), 4-15.

Hojjat panah M, kohan ranjbar z. [Relationship between sexual satisfaction, marital satisfaction and couples life satisfaction]. Amin Outlook Journal in Applied Psychology 2013. (1) 1. (In persian).

honarparvaran n, Tabriz M, Navabinejad. Shafi Abadi AS. [The Effectiveness of Emotion-Oriented Approach on Sexual Satisfaction of Couples]. Thought and Behavior2010. 4 (15). (In persian).

Krannich J.-H. A, Weyers P, Lueger S, Herzog M, Bohrer T, \& Elert O. Presence of depression and anxiety before and after coronary artery bypass graft surgery and their relationship to age. BMC psychiatry; 2007.7(1), 47.

Lengacher CA, Shelton MM, Reich RR, Barta MK, Johnson-Mallard V, Moscoso MS, et al.
Mindfulness based stress reduction) $\operatorname{MBSR}(\mathrm{BC})$ ) in breast cancer. evaluating fear of recurrence (FOR( as a mediator of psychological and physical symptoms in a randomized control trial (RCT). J Behav Med; 2014.37(2):185-95.

Pourangash Tehrani s, etemadi s, Lavasani Gh, AS Sadeghian S. [The Relationship between Psychological Factors and Sexual Disability and Quality of Life in Male Patients after Coronary Artery Bypass Graft Surgery]. Razi Medical Sciences2012. (104), 19-44. (In persian).

Rahimian Booger A, Mahmoudi M, Farahani d, Secretary S. [Comparison of the Effectiveness of Group-Behavioral-Proactive Activation Therapy with Family Support and Without Their Support in Reducing Marital Stress in Coronary Heart Disease Patients]. Cognitive Behavioral Sciences2013. 2 (5), 27-40. (In persian).

roshani ghelci m, Mirza'I p, Nick Azin A. [Reliability and Reliability of Women's Sexual Satisfaction Scale (sssw) in a sample of Iranian women]. Clinical Psychology and Personality2014. 21 (10). (In persian).

Sahabi A, Asghari m C, Salary Rhs. [Validation of Depression Anxiety Scale (DASS-21) for Iranian population]. Iranian Joumal of Psychology2005. 1 (4), 299-310. (Persian).

Shamsipur h, besharat m, Sadeghian S. [ Relationship between marital stress and depression symptoms in women with coronary heart disease and healthy women]. Joumal of Psychology and Educational Sciences2006. (2) 35, 21-37. (In persian).

Shamsipur h, besharat m, Sadeghian S. [ Relationship between marital stress and depression symptoms in women with coronary heart disease and healthy women]. Joumal of Psychology and Educational Sciences1995. 35 (2), 21-37. (In persian).

Shayan A, Khalili A, Rahnavardi M, Masoumi SZ. [The Relationship between Sexual Function and Mental Health of Women with Breast Cancer]. Scientific Joumal of Hamedan 
Nursing and Midwifery Faculty2016. (4) 24. (In persian).

Siavash S, Rosandel M, Zarean A, Casualties 1. [The Effect of Cardiac Rehabilitation Care Program on Quality of Life in Patients under Coronary Artery Bypass Graft] . Joumal of Cardiovascular Nursing2012 . 1 (2). (In persian).

Trudel G,Goldfarb MR. Marital and sexual functioning and dysfunctioning, depression and anxiety, Sexologies; 2010. 19(3),137-142.
Wang H.X, Leineweber C, Kirkeeide R, Svane B, Schenck-Gustafsson K, Theorell T, and OrthGomér K. Psychosocial stress and atherosclerosis: family and work stress accelerate progression of coronary disease in women. The Stockholm Female Coronary Angiography Study. Joumal of Internal Medicine; 2007. 261(3), 245-254.

Yoo H, Bartle-Haring S, Day R.D, \& Gangamma R. Couple communication, emotional and sexual intimacy, and relationship satisfaction. J Sex Marital Ther, 2014.40(4), 275-93. 